\title{
Seasonality in Nutrient Contents of Edible Green Algae Ulva compressa and Ulva fasciata from Southeast Coast of India
}

\author{
N. Monisha Hyderali ${ }^{1^{*}}$, M. Ganesan ${ }^{2}$ and K. Eswaran ${ }^{3}$ \\ ${ }^{1,2 \& 3}$ Marine Algal Research Station, Division of Biotechnology and Psychology, \\ Central Salt and Marine Chemicals Research Institute, (Council of Scientific and Industrial Research), \\ Mandapam Camp, Ramanathapuram District, Tamil Nadu, India \\ *Corresponding Author \\ E-Mail: monisha.bio1@gmail.com
}

\begin{abstract}
Seasonal variations in the proximate (protein, carbohydrate, dietary fiber, ash, moisture, lipid, amino acid and fatty acid content), mineral composition ( $\mathrm{Na}, \mathrm{K}, \mathrm{Ca}, \mathrm{Mg}$, $\mathrm{Fe}, \mathrm{Zn}, \mathrm{C}, \mathrm{Mn})$ and Heavy metals content $(\mathrm{Cd}, \mathrm{Pb}, \mathrm{Hg}$ and $\mathrm{Ni})$ of Ulva compressa and Ulva fasciata were investigated for all four different seasons (Spring, North east monsoon, Summer and South west monsoon) during 2015 to 2016. Data were analyzed using one- and two-way ANOVA. Significant variations in the proximate constituents were found among seasons and species. Maximum proximate and mineral composition in $U$. compressa are protein, carbohydrate, ash content, moisture content and lipid in northeast monsoon, dietary fiber, amino acids content and mineral content in southwest monsoon, fatty acids content in spring. Heavy metals were not detected except lead. In $U$. fasciata, maximum proximate and mineral composition are protein, carbohydrate, moisture content, ash content in spring season, dietary fiber in summer season, lipid and total amino acids content in northeast monsoon, fatty acids contents and mineral content in southwest season. Heavy metals were not detected except lead. $U$. compressa has highest protein, carbohydrate, moisture content, amino acids and mineral content as compared to $U$. fasciata. $U$. fasciata has maximum dietary fiber, ash content, lipid content and fatty acids as compared to $U$. compressa. In general, Northeast monsoon showed the highest proximate and mineral composition in both the algae. The present study revealed that these two edible algae have higher proximate contents which can be more ideal for food consumption for humans and animals.

Keywords: Ulva compressa, Ulva fasciata, Seasonal Variations, Proximate Analysis, Fatty Acids, Amino Acids, Mineral, Nutritional
\end{abstract}

\section{INTRODUCTION}

With increasing population and declining terrestrial food resources due to rapid urbanization, industrialization and water shortage for irrigation, there is an urgent need to develop and implement innovative food production strategies particularly from utilizing vast marine resources. Among the marine organisms, seaweeds are the best renewable resource as nutritional food. Seaweeds have long been part of the traditional diet for the people in China, Japan and Korea for over 2000 years. The nutritional benefits of seaweeds have been well documented in the literature. They are rich in protein (20 to $30 \%$ of their dry weight), extraordinary wealth of mineral elements and higher content of iodine, calcium, magnesium, potassium, iron, vitamins $\mathrm{C}$ and $\mathrm{A}$, protein, Vitamins $\mathrm{B}$, fiber and, alpha linoleic acid and others (Norziah et al., 2002), Among the various species of green algae Ulva are used for human consumption in Japan, East Asia, West and South-East Asia, North and South America. Other species of green algae are also found their application as human food and medicine in certain regions (Johnston, 1966; Neish, 1976; Saito, 1976 \& Chapman, 1970). Ulva spp. are the best nutritional source as they contain high percentage of protein (16-22\%) carbohydrate (43-60\%) and ash content (12-18\%) as dry matter, rich amount of minerals such as calcium, magnesium, iron etc. and all vitamins (Percival 1979; Msuya and Neori 2008). The nutritional benefits of foods made out of these seaweed supplements in many cases surpass those diets based on terrestrial plant foods, improving amino acid balance and quality and quantity of important biochemical components (Freile and Robledo 1997; McDermid and Stuercke 2003; Matanjun et al., 2009). Considering the commercial importance of these algae, the seasonal variation of proximate compositions (protein, carbohydrate, lipid, dietary fiber, ash), amino acid, fatty acid content, minerals composition $(\mathrm{Na}, \mathrm{K}, \mathrm{Ca}, \mathrm{Mg}$, $\mathrm{Fe}, \mathrm{Zn}, \mathrm{C}, \mathrm{Mn})$ and Heavy metals content $(\mathrm{Cd}, \mathrm{Pb}, \mathrm{Hg}$ and $\mathrm{Ni}$ ) of green algae Ulva compressa and Ulva fasciata were analyzed and the results obtained on these aspects are presented in this paper.

\section{MATERIALS AND METHODS}

\section{A. Sample Collection}

Green alga Ulva compressa was collected from marine coastal region of Thonithurai, Mandapam $\left(09^{\circ} 16.974^{\prime} \mathrm{N}\right.$ $\left.079^{\circ} 11.212^{\prime} \mathrm{E}\right)$ and Ulva fasciata from Kanyakumari coastal waters $\left(08^{\circ} 04.673^{\prime} \mathrm{N} 77^{\circ} 32.038^{\prime} \mathrm{E}\right)$ southeast coast of India. To determine seasonal variations, samples were collected in December 2015 (North East Monsoon season) February 2016 (Spring season), April 2016 (Summer season) and August 2016 (South West monsoon season). The algal samples were collected in polythene bags and brought to the laboratory for biochemical characterization. In the laboratory, the samples were washed repeatedly with seawater, under running tap water and then distilled water to 
remove all unwanted impurities, adhering sand particles and epiphytes. The water was drained off and seaweeds were spread on blotting paper to remove excess water and then shade dried at room temperature. Dried seaweeds were ground to make powder and analyses of biochemical compositions were carried out.

B. Proximate Composition: Standard protocols were followed for the estimation of proximate composition.

1. Protein Content: The protein content was analyzed by the revised method of Lowry et al., (Hartree, 1972) with bovine serum albumin as standard.

2. Carbohydrate Content: The total carbohydrate was estimated by following the Phenol-sulphuric acid method of Dubois et al., (1956) with glucose as a standard.

3. Lipid content: The extraction of lipid was done by the chloroform-methanol mixture (Folch et al., 1957).

4. Dietary Fiber: The fiber content of the dried seaweeds was determined using a standard method outlined by AOAC (1985) by Gravimetry method. Here, the acid hydrolysis was carried out with sulfuric acid $(0.3 \mathrm{~N}$ $\mathrm{H} 2 \mathrm{SO} 4)$ and the base hydrolysis was undertaken using sodium hydroxide $(0.5 \mathrm{~N} \mathrm{NaOH})$. The cold extraction was performed with acetone. The samples were then dried $\left(1 \mathrm{~h}\right.$ at $\left.110^{\circ} \mathrm{C}\right)$ until it reached a constant weight, cooled in a desiccators and weighed (W1); thereafter, it was placed in a muffle furnace at $550{ }^{\circ} \mathrm{C}$ for $3 \mathrm{~h}$, cooled (in a desiccators) and reweighed (W2). The crude fiber percentage was calculated following the equation: \% crude fiber $=(\mathrm{W} 1-\mathrm{W} 2 / \mathrm{W} 0) \times 100($ wherein, $\mathrm{W} 0$ was the initial weight of the dried seaweed).

5. Ash Content: The ash content of the sample was determined using standard method (AOAC, 1995).The ash content was analyzed by shade drying the samples at room temperature and later in an oven at $80{ }^{\circ} \mathrm{C}$ for 1 $\mathrm{h}$, thereafter, one gram of the powdered sample was accurately taken in a crucible, ashed at $550{ }^{\circ} \mathrm{C}$ in muffle furnace for $6 \mathrm{~h}$ to a constant weight, and the ash obtained was then quantified gravimetrically.

6. Moisture Content: For the determination of moisture content, the samples were dried at $100 \pm 2{ }^{\circ} \mathrm{C}$ for obtaining a constant weight (AOAC, 2006).

7. Lipid Content: Total lipids of the seaweed samples were analyzed by following the gravimetric method of Folch et al., (1956). One gram of tissue was homogenized in $20 \mathrm{ml}$ of chloroform - methanol mixture at 2:1 ratio. It was then left undisturbed for 2 hours in the dark and then filtered through a Whatmann No.1 filter paper and kept overnight in the dark in a pre-weighed beaker. After total evaporation, the beaker was weighed again and from the difference, the weight of the lipid in the sample was calculated.

8. Analysis of Amino Acid: Estimation of amino acid composition in both seaweeds has been carried out as per the procedure outlined in standard manual USP30NF25 Pharmacopeial Forum (2013). The amino acid composition of dried samples were determined by hydrolyzing the samples in $6 \mathrm{~N} \mathrm{Hcl}$ for 24 hours at $110^{\circ} \mathrm{C}$. The acid was removed by vacuum evaporation made up to a known volume with $0.05 \mathrm{~N} \mathrm{Hcl}$ and then analysed using HPLC.

9. Estimation of Fatty Acid by Gas Chromatography: Analysis of fatty acid composition in both seaweeds has been carried out as per the procedure outlined in standard manual USP $30 \mathrm{NF} 25$ Pharmacopial forum (2013).

10. Mineral Compositions: Samples for mineral analysis were subjected to acid digestion and analyzed through Atomic Absorption Spectrophotometry (AAS) following the procedures described by USP27-NF22 pharmacopial forum (2013).Estimation of various minerals such as copper, zinc, sodium, potassium, magnesium etc., has been carried out as per the procedure outlined in standard manual of USP pharmacopeia (2013).

11. Heavy Metal Analysis: Estimation of various heavy metals such as, nickel $(\mathrm{N})$, cadmium $(\mathrm{Cd})$, lead $(\mathrm{Pb})$ and mercury $(\mathrm{Hg})$ has been carried out as per the procedure outlined in standard manual of USP27-NF22 Pharmacopial forum (2013). $10 \mathrm{gm}$ of the collected seaweed samples (from each station) were dried at $60^{\circ} \mathrm{C}$ overnight. Each dried sample (1 gm on dry weight basis) was digested with a mixture of nitric acid and hydrogen peroxide followed by addition of hydrochloric acid. Organic matter in sample is digested by wet digestion or dry digestion or high pressure microwave digestion and determine the amount of heavy metals, i.e. nickel $(\mathrm{N})$, cadmium $(\mathrm{Cd})$, lead $(\mathrm{Pb})$ and mercury $(\mathrm{Hg})$ by using graphite furnace atomic absorption spectrophotometer (GF-AAS) and flow injection analysis system -atomic absorption spectrophotometer (FIAS-AAS). Blank correction was carried out to bring accuracy to the results.

12. Statistical Analysis: All the samples were analyzed in triplicates and the values are presented as mean values of triplicate determinations \pm Standard Deviation. The data were subjected to one way and two way analysis of variance (ANOVA) and difference in significance of its means were calculated by Turkey's test level at $\mathrm{p}<0.05$ by using SYSTAT software.

\section{RESULTS}

\section{A. Seasonal Variations}

Seasonal variations in the proximate compositions of seaweeds on dry weight basis are shown in Table I. The protein content in U. compressa ranged from $43.21 \%$ in northeast monsoon season to $37.91 \%$ in summer season. ANOVA showed significant variations $(\mathrm{F}=18.699$; $\mathrm{df}=3$, $8 ; \mathrm{P}<0.001)$ between seasons. While the protein content in $U$. fasciata ranged from $34.99 \%$ in spring season to $28.12 \%$ in southwest monsoon season. ANOVA showed significant variations $(\mathrm{F}=27.832 ; \mathrm{df}=3,8 ; \mathrm{P}<0.001)$ between seasons. Generally, protein content was highest in $U$. compressa and showed significant variation when compared with $U$. fasciata $(\mathrm{F}=14.272 ; \mathrm{df}=3,1 ; \mathrm{P}<0.032)$. 
TABLE I SEASONAL VARIATION IN BIOCHEMICAL COMPOSITION (\% DRY WT.) OF ULVA COMPRESSA AND ULVA FASCIATA

\begin{tabular}{|l|c|c|c|c|c|c|c|c|}
\hline \multicolumn{1}{|c|}{ Seaweed } & \multicolumn{4}{|c|}{ Ulva compressa } & \multicolumn{4}{c|}{ Ulva fasciata } \\
\hline \multicolumn{1}{|c|}{ Seasons } & Spring & Northeast & Summer & Southwest & Spring & Northeast & Summer & Southwest \\
\hline Protein & 37.96 & 43.21 & 37.91 & 39.25 & 34.99 & 34.01 & 32.91 & 28.12 \\
\hline Carbohydrate & 12.45 & 24.39 & 10.45 & 20.15 & 10.24 & 9.24 & 9.34 & 2.34 \\
\hline Dietary fiber & 1.35 & 1.44 & 1.93 & 2.01 & 1.93 & 1.35 & 20.77 & 3.13 \\
\hline Ash content & 14.65 & 18.93 & 15.30 & 15.65 & 30.68 & 19.04 & 1.35 & 14.23 \\
\hline Moisture & 87.56 & 89.11 & 84.73 & 87.04 & 76.03 & 74.62 & 73.65 & 73.89 \\
\hline Lipid content & 0.81 & 0.88 & 0.75 & 0.79 & 0.90 & 1.1 & 0.89 & 0.87 \\
\hline
\end{tabular}

The carbohydrate content in $U$. compressa ranged from $24.39 \%$ in northeast monsoon season to $10.45 \%$ in summer season. ANOVA showed significant variations $(\mathrm{F}=$ 128.121; df = 3, 8; $\mathrm{P}<0.001)$. Similarly, the carbohydrate content in $U$. fasciata ranged between $10.24 \%$ in spring season and $2.34 \%$ in southwest monsoon season. ANOVA showed significant variations $(\mathrm{F}=40.210$; $\mathrm{df}=3,8 ; \mathrm{P}<$ $0.001)$ between seasons. Carbohydrate content was highest in $U$. compressa and showed no significant variation with U. fasciata $(\mathrm{F}=4.411 ; \mathrm{df}=3,1 ; \mathrm{P}<0.126)$.

The dietary fiber content in Ulva compressa ranged from $2.01 \%$ in southwest monsoon season to $1.35 \%$ in spring season. ANOVA showed no significant variations $(\mathrm{F}=$ 0.341 ; df $=3$, 8; $\mathrm{P}<0.797$ ) between seasons. Similarly, dietary fiber content in $U$. fasciata ranged from $20.77 \%$ in summer to $1.35 \%$ in northeast monsoon season ANOVA showed significant variations $(\mathrm{F}=262.049$; $\mathrm{df}=3,8 ; \mathrm{P}<$ $0.001)$. Dietary fiber content was highest in $U$. fasciata and showed no significant variation with $U$. compressa $(\mathrm{F}=$ 1.2440; df = 3, $1 ; \mathrm{P}<0.345)$.

The ash content in $U$. compressa ranged from $18.93 \%$ in northeast monsoon to $14.65 \%$ in spring season. ANOVA showed significant variations $(\mathrm{F}=10.950$; $\mathrm{df}=3,8 ; \mathrm{P}<$ $0.003)$. Likewise the ash content in $U$. fasciata ranged between $30.68 \%$ in spring season and $1.35 \%$ in summer season. ANOVA showed significant variations $(\mathrm{F}=$ 441.998; df $=3,8 ; \mathrm{P}<0.001)$ between seasons. The ash content was highest in $U$. fasciata and showed no significant variation with $U$. compressa $(\mathrm{F}=0.000964$; $\mathrm{df}=$ $3,1 ; \mathrm{P}<0.977)$.

The moisture content in $U$. compressa ranged from $89.11 \%$ in northeast monsoon season and $84.73 \%$ in summer season. ANOVA showed significant variations $(\mathrm{F}=19.902$; $\mathrm{df}=3$, $8 ; \mathrm{P}<0.001)$. While the moisture content in $U$. fasciata ranged between $76.03 \%$ in spring season and $73.65 \%$ in summer season. ANOVA showed no significant variations $(\mathrm{F}=3.441 ; \mathrm{df}=3,8 ; \mathrm{P}<0.072)$ between seasons. Moisture content was highest in $U$. compressa and showed significant variation with $U$. fasciata (ANOVA showed significant variations $(\mathrm{F}=41.97573 ; \mathrm{df}=3,8 ; \mathrm{P}<0.007)$.

The lipid content in $U$. compressa ranged from $0.88 \%$ in northeast monsoon season to $0.75 \%$ in summer season. ANOVA showed no significant variations $(\mathrm{F}=0.888$; $\mathrm{df}=$ $3,8 ; \mathrm{P}<0.488)$. While the lipid content in $U$. fasciata ranged from $1.1 \%$ in northeast monsoon season to $0.87 \%$ in southwest monsoon season. ANOVA showed no significant variations $(\mathrm{F}=3.460 ; \mathrm{df}=3,8 ; \mathrm{P}<0.071)$ between seasons. Lipid content was highest in $U$. fasciata and showed significant variation with $U$. compressa $(\mathrm{F}=17.162 ; \mathrm{df}=3$, $1 ; \mathrm{P}<0.025)$.

TABLE II SEASONAL VARIATION OF AMINO ACID COMPOSITIONS (MG.100 ${ }^{-1}$ DRY WT.) ON ULVA COMPRESSA AND ULVA FASCIATA

\begin{tabular}{|c|c|c|c|c|c|c|c|c|}
\hline \multirow{2}{*}{$\begin{array}{c}\text { Amino acid } \\
\text { Seasons }\end{array}$} & \multicolumn{4}{|c|}{ Ulva compressa } & \multicolumn{4}{|c|}{ Ulva fasciata } \\
\hline & $\begin{array}{l}\text { Spring } \\
\text { season }\end{array}$ & $\begin{array}{c}\text { Northeast } \\
\text { monsoon }\end{array}$ & $\begin{array}{c}\text { Summer } \\
\text { season }\end{array}$ & $\begin{array}{c}\text { Southwest } \\
\text { monsoon }\end{array}$ & $\begin{array}{l}\text { Spring } \\
\text { season }\end{array}$ & $\begin{array}{c}\text { Northeast } \\
\text { monsoon }\end{array}$ & $\begin{array}{c}\text { Summer } \\
\text { season }\end{array}$ & $\begin{array}{c}\text { Southwest } \\
\text { monsoon }\end{array}$ \\
\hline \multicolumn{9}{|c|}{ Essential amino acids } \\
\hline Arginine & 430.5 & 3086.4 & 1192.3 & 3093.2 & 189.5 & 198.3 & 241.3 & 109.3 \\
\hline Histidine & 49.3 & 1598.3 & 219.3 & 998.5 & 398.3 & 414.6 & 439.3 & 215.2 \\
\hline Iso-Leucine & 103.7 & 193.6 & 318.6 & 1193.6 & 298.3 & 802.5 & 335.6 & 93.5 \\
\hline Leucine & 189.3 & 203.6 & 1110.5 & 3983.6 & 419.4 & 402.5 & 301.7 & 215.3 \\
\hline Lysine & 209.6 & 2933.6 & 1339.1 & 873.6 & 281.2 & 925.3 & 449.8 & 119.8 \\
\hline Methionine & 39.6 & 151.4 & 1093.5 & 3096.3 & 509.2 & 209.5 & 145.7 & 112.5 \\
\hline Phenylalanine & 118.3 & 1093.6 & 3509.3 & 1895.7 & 892.6 & 199.2 & 429.3 & 109.4 \\
\hline Threonine & 119.3 & 3183.7 & 2883.6 & 1198.6 & 56.5 & 609.4 & 663.7 & 1123.5 \\
\hline Tryptophan & 89.36 & 67.8 & 119.3 & 3903.6 & 121.6 & 209.1 & 43.6 & 809.6 \\
\hline Valine & 120.65 & 209.6 & 893.6 & 1193.7 & 211.1 & 112.5 & 90.3 & 109.3 \\
\hline
\end{tabular}




\begin{tabular}{|l|c|c|c|c|c|c|c|c|}
\hline \multicolumn{10}{|c|}{ Non-essential amino acids } \\
\hline Alanine & 10.54 & 191.5 & 108.6 & 3198.5 & 395.6 & 223.5 & 409.7 & 125.8 \\
\hline Asparagine & 83.6 & 313.6 & 3093.2 & 1135.1 & 198.7 & 456.7 & 410.64 & 125.6 \\
\hline Aspartic acid & 56.5 & 294.6 & 198.6 & 123.6 & 256.9 & 836.4 & 145.6 & 125.6 \\
\hline Cysteine & 193.54 & 183.6 & 214.4 & 2931.6 & 325.6 & 593.6 & 298.4 & 309.2 \\
\hline Glutamic acid & 122.5 & 1093.1 & 2139.6 & 3093.6 & 293.6 & 189 & 390.3 & 109.4 \\
\hline Glutamine & 193.6 & 109.8 & 2099.6 & 3193.7 & 120.6 & 893.6 & 602.7 & 108.7 \\
\hline Glycine & 206.7 & 2193.6 & 3193.1 & 2193.4 & 383.6 & 324.8 & 443.6 & 345.3 \\
\hline Proline & 113.7 & 1036.9 & 409.6 & 1091.4 & 214.3 & 183.5 & 209.1 & 121.3 \\
\hline Serine & 4.45 & 23.7 & 1198.3 & 2098.6 & 32.6 & 213.5 & 523.6 & 112.8 \\
\hline Tyrosine & 129.1 & 3915.7 & 387.6 & 1093.3 & 198.8 & 192.9 & 132.7 & 178.9 \\
\hline
\end{tabular}

The seasonal profiles of all essential and non-essential amino acids in the two seaweed species are presented in Table II. Levels of the different amino acids ranged from 4.45 to 3983.6 (mg.100 $100^{-1}$ rywt.) in $U$. compressa and from 32.6 to 1123.5 (mg.100 ${ }^{-1}$ drywt.) in $U$. fasciata. In both types of seaweed contained a high level of amino acids, especially $U$. compressa regarding essential amino acids; leucine, tryptophan, methionine, arginine in southwest monsoon season and phenylalanine in summer season. On the other $U$. fasciata stands out as having a high level of the essential amino acids threonine, tryptophan in southwest monsoon and lysine in northeast monsoon. In common the amino acid content was higher in $U$. compressa when compared with $U$. fasciata.

Table III Seasonal Variation In Fatty Acid Composition Of Two Green Algae Species (\% Dry Wt.)

\begin{tabular}{|c|c|c|c|c|c|c|c|c|}
\hline & \multicolumn{4}{|c|}{ Ulva compressa } & \multicolumn{4}{|c|}{ Ulva fasciata } \\
\hline Seasons & $\begin{array}{l}\text { Spring } \\
\text { season }\end{array}$ & $\begin{array}{l}\text { Northeast } \\
\text { monsoon }\end{array}$ & $\begin{array}{c}\text { Summer } \\
\text { season }\end{array}$ & $\begin{array}{c}\text { Southwest } \\
\text { monsoon }\end{array}$ & $\begin{array}{l}\text { Spring } \\
\text { season }\end{array}$ & $\begin{array}{l}\text { Northeast } \\
\text { monsoon }\end{array}$ & $\begin{array}{c}\text { Summer } \\
\text { season }\end{array}$ & $\begin{array}{c}\text { Southwest } \\
\text { monsoon }\end{array}$ \\
\hline Palmitic acid (C16:0) & 0.397 & 0.016 & 0.013 & 0.010 & 1.04 & 0.983 & 1.035 & 1.56 \\
\hline Margaric acid (C17:0) & 0.011 & 0.184 & 0.123 & 0.103 & 2.13 & 0.42 & 0.056 & 0.384 \\
\hline Stearic acid (C18:0) & 1.846 & 0.292 & 0.174 & 0.119 & 2.89 & 2.98 & 0.894 & 1.98 \\
\hline${ }^{1}$ Saturated fatty acids & 2.254 & 0.491 & 0.309 & 0.232 & 6.06 & 4.383 & 1.984 & 1.308 \\
\hline Oleic acid $(\omega 9)(\mathrm{C} 18: 1)$ & 2.016 & 0.194 & 0.204 & 0.206 & 0.36 & 1.36 & 0.494 & 2.44 \\
\hline $\begin{array}{l}{ }^{2} \text { Monounsaturated fatty } \\
\text { acids }\end{array}$ & 2.016 & 0.194 & 0.204 & 0.206 & 0.36 & 1.36 & 0.493 & 2.44 \\
\hline Linoleic acid $(\omega 6)(\mathrm{C} 18: 2)$ & 3.044 & 0.202 & 0.119 & 0.135 & 1.35 & 1.65 & 0.393 & 4.09 \\
\hline $\begin{array}{l}\alpha \text { Linolenic acid }(\omega 3) \\
(\mathrm{C} 18: 3)\end{array}$ & 2.989 & 0.194 & 0.210 & 0.119 & 0.18 & 1.98 & 0.129 & 3.29 \\
\hline Morotic acid (C18:4) & 0.126 & 0.011 & 0.019 & 0.004 & 0.42 & 0.545 & 0.045 & 1.93 \\
\hline${ }^{3}$ Polyunsaturated fatty acids & 6.159 & 0.406 & 0.348 & 0.258 & 1.950 & 4.175 & 0.567 & 9.310 \\
\hline
\end{tabular}

1. Total saturated fatty acids (SFAs) $=$ the sum of $\mathrm{C} 16: 0$ to $\mathrm{C} 18: 0$ 2. Total mono unsaturated fatty acids (MUFAs) $=$ the amount of $\mathrm{C} 18: 1$

3. Total poly unsaturated fatty acids (PUFAs) $=$ the sum of $\mathrm{C} 18: 2$ to $\mathrm{C} 18: 4$

The fatty acid composition of the seaweeds under study is shown in Table III. In the two samples studied the most abundant essential fatty acid was Linoleic acid $(\omega 6)(\mathrm{C} 18: 2)$ and $\alpha$ Linoleic acid $(\omega 3)(\mathrm{C} 18: 3)$, which in $U$. compressa it was found to be $3.044 \%$ and $2.989 \%$; U. fasciata accounted for $4.09 \%$ and $3.29 \%$. Although our investigation showed that both seaweeds have higher total levels of PUFAs than MUFAs and SFAs i.e. PUFAs $6.159 \%$ in spring season in $U$. compressa, $9.310 \%$ in southwest monsoon in $U$. fasciata, and SFAs $2.254 \%$ in spring season in $U$. compressa, $6.06 \%$ in spring season in U. fasciata. Saturated FAs were predominant in both seaweeds during spring. This was due mainly to the presence of stearic (C18:0) and palmitic acid (C16:0). MUFAs were dominant in 2.016 in spring season in $U$. compressa whereas, $2.44 \%$ in southwest monsoon season in U. fasciata.

The mineral content of two algae is represented in Table IV. The highest calcium (148mg.100-1 drywt.), zinc (18.3mg. $100^{-1}$ drywt.) were higher in northeast monsoon followed by magnesium (12.8mg. $100^{-1}$ drywt.), copper (209.6mg. $100^{-1}$ drywt.) and potassium (89.3 mg.100 ${ }^{-1}$ drywt.) in southwest monsoon season in $U$. compressa followed by spring and summer. In $U$. fasciata, calcium (184.3mg. $100^{-}$ ${ }^{1}$ drywt.), magnesium (50.4mg.100 10 drywt.) sodium (193.6mg. $100^{-1}$ drywt.) and potassium (56.3mg.100 $0^{-1}$ drywt.) contents were found in summer followed by spring, northeast and southwest monsoon. 
TABLE IV SEASONAL VARIATION IN MINERAL COMPOSITION (MG. 100 $10{ }^{-1}$ DRY WT.) OF ULVA COMPRESSA AND ULVA FASCIATA

\begin{tabular}{|l|c|c|c|c|c|c|c|c|}
\hline & \multicolumn{4}{|c}{ U. compressa } & \multicolumn{4}{c|}{ U.fasciata } \\
\hline & $\begin{array}{c}\text { Spring } \\
\text { season }\end{array}$ & $\begin{array}{c}\text { Northeast } \\
\text { monsoon }\end{array}$ & $\begin{array}{c}\text { Summer } \\
\text { season }\end{array}$ & $\begin{array}{c}\text { Southwest } \\
\text { monsoon }\end{array}$ & $\begin{array}{c}\text { Spring } \\
\text { season }\end{array}$ & $\begin{array}{c}\text { Northeast } \\
\text { monsoon }\end{array}$ & $\begin{array}{c}\text { Summer } \\
\text { season }\end{array}$ & $\begin{array}{c}\text { Southwest } \\
\text { monsoon }\end{array}$ \\
\hline Calcium & 76.9 & 148.9 & 39.56 & 30.35 & 67.7 & 31.6 & 184.3 & 12.5 \\
\hline Magnesium & 12.3 & 0.839 & 10.93 & 12.88 & 12.3 & 8.24 & 50.4 & 1.03 \\
\hline Zinc & 1.56 & 18.3 & 1.96 & 1.25 & 10.02 & 11.14 & 1.48 & 0.45 \\
\hline Iron & 13.39 & 1.08 & 5.16 & 3.54 & 4.34 & 0.95 & 1.54 & 2.34 \\
\hline Sodium & 156.7 & 146.7 & 193.6 & 189.5 & 193.6 & 124.6 & 193.6 & 25.66 \\
\hline Copper & 0.24 & 0.419 & 0.21 & 209.6 & 0.43 & 1.29 & $2.11 \mathrm{mcg}$ & 1.32 \\
\hline Potassium & 10.6 & 15.6 & 23.7 & 89.3 & 19.2 & 32.5 & 56.3 & 1.55 \\
\hline Manganese & traces & 0.035 & 1.33 & $12.5 \mathrm{mcg}$ & 0.15 & 0.98 & 1.89 & 2.35 \\
\hline
\end{tabular}

TABLE V SEAsonal Variation In HEAVy Metals (PPM) OF ULVA COMPRESSA AND ULVA FASCIATA

\begin{tabular}{|l|c|c|c|c|c|c|c|c|}
\hline & \multicolumn{4}{|c|}{ U. compressa } & \multicolumn{4}{c|}{ U.fasciata } \\
\hline Heavy metals & Spring & Northeast & Summer & Southwest & Spring & Northeast & Summer & Southwest \\
\hline Lead & $<5$ & $<5$ & $<5$ & $<1$ & $<5$ & $<5$ & $<2$ & 1.28 \\
\hline Cadmium & ND & ND & ND & ND & ND & ND & ND & 0.25 \\
\hline Nickel & ND & ND & ND & ND & ND & ND & ND & ND \\
\hline Mercury & ND & ND & ND & ND & ND & ND & ND & ND \\
\hline
\end{tabular}

The heavy metals were shown in Table V. The heavy metals like cadmium $(\mathrm{Cd})$, nickel $(\mathrm{Ni})$ and mercury $(\mathrm{Hg})$ were not detected in both $U$. compressa and in U. fasciata. While the lead content was $<1 \mathrm{ppm}$ in southwest monsoon, while $<5 \mathrm{ppm}$ in all other three seasons in $U$. compressa. In $U$. fasciata lead content was found to be $<5 \mathrm{ppm}$ in spring and northeast monsoon, <2ppm in summer and $1.28 \mathrm{ppm}$ in southwest.

\section{DISCUSSION}

The report on distribution and seasonal variation of proximate, nutritional and chemical composition of marine algae from Indian coastal environment are inadequate. The present study dealt with seasonal variation of proximate composition of green algae Ulva compressa and Ulva fasciata studied for four seasons.

Maximum proximate composition in $U$. compressa are protein $(43.21 \%)$ carbohydrate $(24.39 \%)$, lipid $(0.8 \%)$, moisture content $(89.11 \%)$, dietary fiber $(2.01 \%)$, ash content $(18.93 \%)$, In $U$. fasciata, maximum proximate composition are protein (34.99), carbohydrate $(10.24 \%)$ lipid $(1.11 \%)$, moisture content $(76.03 \%)$, dietary fiber (20.77), ash content $(30.68 \%)$, U. compressa has highest protein, carbohydrate, moisture content as compared to $U$. fasciata. Burtin (2003) reported that the protein content in green and red seaweeds are generally higher (ranging from $10 \%$ to $30 \%$ ) as compared to brown seaweeds (ranging from $5 \mathrm{~h}$ to $15 \%$ ). The biochemical composition of seaweeds differs and is affected by inflow of land sources, geographic area and season of the year and temperature of water (Jenson, 1993). The variation in ash content could be related to habitat, the habitats may have varying amounts of inorganic compounds and salts, additionally, temperature and $\mathrm{pH}$ could have an influence on mineralization (Mendis \& Kim, 2011; Polat \& Ozogul, 2009).

Seasonality in proximate composition showed protein, carbohydrate, lipid, moisture, ash contents are high in $U$. compressa in Northeast monsoon season whereas dietary fiber content is high in southwest monsoon season. Similarly, proteins, carbohydrate, moisture, ash content are high in $U$. fasciata in spring season, lipid in northeast monsoon season and dietary fiber in summer season. In general, northeast monsoon showed the highest proximate composition.

The variation in protein content in seaweeds could be attributed to differences in seasonality and growth conditions in the environment (Dawczynski et al., 2007). The variation in ash content could be related to habitat, the habitats may have varying amounts of inorganic compounds and salts, additionally, temperature and $\mathrm{pH}$ could have an influence on mineralization (Mendis \& Kim, 2011; Polat \& Ozogul, 2009). Apart from the species specific difference, geographical location and local environmental condition can influence the proximate composition of seaweeds (RohaniGhadikolalel et al., 2012).

The major essential amino acids viz. leucine, tryptophan, phenylalanine, methionine, arginine are rich in $U$. compressa. Similarly, the non-essential amino acids in tyrosine, glycine, glutamine, asparagine and glutamic acid are rich in $U$. compressa. While major essential amino acids threonine, lysine, phenylalanine, tryptophan, iso-leucine, 
and methionine are rich in $U$. fasciata. The most limiting essential amino acid of both species was lysine. The highest leucine content was found to be (3983. $6 \mathrm{mg}^{1} 100^{-1} \mathrm{drywt}$ ) in $U$. compressa, while the threonine was found to be higher in $U$. fasciata (1123. 5mg. $100^{-1}$ drywt.). However, the nutritional Composition of the two seaweeds varied depending on seasonal change. When compared with $U$. fasciata the amino acid content is higher in U. compressa in all seasons.

In $U$. compressa, the essential amino acids; leucine, tryptophan, methionine, arginine were highest in southwest monsoon and phenylalanine in summer. While non-essential amino acids asparagine, glutamic acid and glycine are higher in summer season. On the other $U$. fasciata stands out as having a high level of the essential amino acids threonine, tryptophan in southwest monsoon and lysine in northeast monsoon. Non-essential amino acids like glutamine and aspartic acid were higher in northeast monsoon.

The fatty acid compositions $U$. compressa were in the following ranges: saturated (SFA) - $2.254 \%$, monounsaturated (MUFAs)-2.016\% and polyunsaturated fatty acids (PUFAs) $-6.159 \%$, while in $U$. fasciata, saturated (SFA) $-6.06 \%$, monounsaturated (MUFAs) $-2.44 \%$ and polyunsaturated fatty acids (PUFAs) $-9.310 \%$ were higher. Li et al., (2002) and Khotimchenko et al., (2002) reported that Linoleic acid (18:2n-6) is the main PUFA of most chlorophytes and the $\alpha$-linolenic acid (18:3n-3) is characteristic of the Ulvales. According to the literature, palmitic acid (16:0) is predominant in seaweeds reported by Gressler et al., 2010, while it was higher $1.159 \%$ in $U$. fasciata.

In $U$. compressa the maximum FAs were produced during spring season. Saturated, monounsaturated and polyunsaturated FAs were predominant during spring season. The saturated FAs was due mainly to the presence of Stearic acid (C18:0) and palmitic acid (C16:0), which made up $1.846 \mathrm{~g} / 100 \mathrm{gms}$, the monounsaturated FAs mainly contains Oleic acid ( $\omega 9)$ (C18:1) and polyunsaturated FAs like Linoleic acid $(\omega 6)$ (C18:2), $\alpha$ Linoleic acid ( $\omega 3)$ (C18:3) were rich. In U. fasciata polyunsaturated and monounsaturated FAs were higher in southwest monsoon; saturated FAs were higher in northeast monsoon. Fatty acids were rich in $U$. fasciata when compared with $U$. compressa.

Palmitic acid was also the major FA $(85.36 \%)$ in Gellidum micropterum (Venkatesalu et al., 2004), in Porphyra spp. (63.19\%) (Sanchez-Machado et al., 2004) and in other algal species like Ergrezia menziesii, Chondracanthus canaliculatus and Ulva lobata (Nelson et al., 2002) as well as in Sargassum species (Hamdy \& Dawes 1998). This can be attributed to the influence of environmental factors and/or characteristic features of the individual genera (Khotimchenko 1991).

$U$. compressa was rich in $\mathrm{Ca}, \mathrm{Na}$, and $\mathrm{Cu}$ content, while $U$. fasciata was rich in macro-minerals like $\mathrm{Ca}, \mathrm{Na}$, and $\mathrm{Mg}$ than other minerals. Comparing the element contents of the two species, $U$. fasciata was rich in $\mathrm{Ca}, \mathrm{Mg}$ and $\mathrm{K}$. In common both have same sodium levels. The trace elements like manganese were found in almost all seasons trace levels- $1.33 \mathrm{mg} / 100 \mathrm{~g}$ obtained in $U$. compressa, $0.15-2.35$ in $U$. fasciata. All seaweeds contain large amounts of both macro-minerals ( $\mathrm{Ca}, \mathrm{Mg}, \mathrm{Na}, \mathrm{P}$ and $\mathrm{K}$ ) and trace elements (Zn, I and Mn) (Matanjun et al., 2009, Polat \& Ozogul 2009). The elevated level of $\mathrm{Cu}$ in marine environment is an indicator of pollution, which is originated by household and industrial wastes.

In this seasonal study, in $U$. compressa $\mathrm{Ca}$ and $\mathrm{Zn}$ were rich in northeast monsoon $\mathrm{Cu}, \mathrm{K}, \mathrm{Mg}$ were rich in southwest monsoon and $\mathrm{Na}$ ad $\mathrm{Mn}$ were rich in summer season. In $U$. fasciata $\mathrm{Ca}, \mathrm{Mg}, \mathrm{K}$ and $\mathrm{Na}$ were rich in summer season, $\mathrm{Zn}$ were rich in northeast monsoon, $\mathrm{Fe}$ in spring season. $U$. compressa had the highest levels of potassium 89.3 (mg.100 $0^{-1}$ drywt.) in southwest monsoon while $U$. fasciata had the highest 56.3 (mg.100 $100^{-1}$ drywt.) in summer season. Potassium content in both species of Ulva were lesser than $520 \mathrm{mg} / 100 \mathrm{~g}$ reported by Rohani-Ghadikolaei et al., (2012) and $4340 \mathrm{mg} / 100 \mathrm{~g}$ obtained by Kumar et al., (2011) in Ulva species. Seaweeds generally contain $8-40 \%$ of minerals, and the essential minerals and trace elements needed for human nutrition are present in seaweeds (Mabeau \& Fleurence 1993). The mineral contents of seaweeds are reported to vary according to such factors as species, geographical origin, and seasons, environmental and physiological variations (Mabeau \& Fleurence 1993, Kaehler \& Kennish 1996).

In all season's cadmium, mercury and nickel were not detected in both the species except the cadmium was found $0.25 \mathrm{ppm}$ in southwest monsoon season in $U$. fasciata. Concentrations of heavy metals in macro algae showed that in both Ulva spp. lead was found less than $5 \mathrm{ppm}$ all season. The rainfall was the parameter that presented greater influence on the metals accumulation, while salinity was the most relevant factor in the environment, preventing absorption of metals in the algae.

\section{CONCLUSION}

Ulva compressa and Ulva fasciata contain rich source of Protein, minerals mainly calcium and potassium, essential amino acids and fatty acids. Therefore, these algae form the best nutritional source. India with more than $8100 \mathrm{~km}$ long coastline has abundant Ulva biomass. These algae can be given importance to be a part of nutritional food in our regular diet.

\section{ACKNOWLEDGEMENT}

We gratefully acknowledge Ministry of New and Renewable Energy (MNRE) for funding support. We would like to thank to Dr. Amitava Das, Director, CSMCRI, Dr. Pradeep K Agarwal, Principal Scientist and Dr. Vaibhav A. Mantri, Senior Scientist for encouragement to carry out the work. 


\section{REFERENCES}

[1] M.H. Norziah, C.Y. Ching, "Nutritional composition of edible seaweeds Gracilaria changgi", Food Chemistry., Vol. 68, No. 1, pp. 69-76, 2002.

[2] H.W. Johnston, "The biological and economic importance of algae", 2. Algae as Food. Tuatara, Vol. 141, 30-66, 1966.

[3] A.C. Neish, "Culture of algae and seaweeds", FAO Technical Conference on aquaculture, Kyoto, 1976.

[4] Y. Saito, "Seaweed aquaculture in the North-West Pacific", FAO Technical Conference on aquaculture, Kyoto, 1976.

[5] V.J. Chapman, "Seaweeds and their uses", Methuen and Co. Ltd., London, 1970.

[6] E. Percival, "The polysaccharides of green, red and brown seaweeds: their basic structure, biosynthesis and function", Journal of British Phycology, Vol. 14, No. 2, pp. 103-11, 1979.

[7] F.E. Msuya and A. Neori, "Effect of water aeration and nutrient load level on biomass yield, $\mathrm{N}$ uptake and protein content of the seaweed Ulva lactuca cultured in seawater tanks", Journal of applied Phycology, Vol. 20, pp. 1021-1031, 2008.

[8] D. Robledo, and Y.F. Pelegrin, "Chemical and mineral composition of six potentially edible seaweed species of Yucatan", Botanica Marina, Vol. 40, pp. 301-306, 1997.

[9] K.J. McDermid, and B. Stuercke, "Nutritional composition of edible Hawaiian seaweeds", Journal of Applied Phycology, Vol. 15, No.6, pp. 513-524, 2003.

[10] P. Matanjun, S. Mohamed, N.M. Mustapha, and K. Muhammad, "Nutrient Content of Tropical Edible Seaweeds, Eucheuma cottonii, Caulerpa lentillifera and Sargassum polycystum", Journal of Applied Phycology, Vol. 21, No.1, pp. 75-80, 2009.

[11] E.E. Hartree, "Determination of protein; A modification of the Lowry method that gives a linear photometric response", Analytical Biochemistry, Vol. 48, 422-427, 1972.

[12] M. Dubois, K.A Gilles, J.K. Hamilton, P.A. Rebor and F. Smith, "Colorimetric Method for Determination of Sugars and Related Substances", Analytical chemistry, Vol. 28, pp. 350-356, 1956.

[13] AOAC, Official Method of Analysis "Total Dietary Fiber in FoodsEnzymatic-Gravimetric Method, adopted. Method becomes de facto working definition for dietary fiber", Vol. 29, 1985.

[14] AOAC, "Association of Official Analytical Chemists, Official Methods for Analysis", 16th edition. AOAC, Washington, D.C, 1995.

[15] AOAC, "Official Methods of Analysis of AOAC International", 20th Edition, AOAC, Arlington, VA, 2006.

[16] J. Folch, M. Lees, G.H. Solane-Stanley, "A simple method for the isolation and purification of total lipids from animal tissues", Journal Biological Chemistry, Vol. 226, pp. 497-509, 1956.

[17] Staff Liaison: Lawrence Evans, "Estimation of amino acids by HPLC analysis. Senior Scientific Associate, Expert Committee: (DSN) Dietary Supplements: Non-Botanicals", USP30-NF25 Page 1442, Pharmacopeial Forum: Vol. 31, No. 5, pp.1345, 2013.

[18] Staff Liaison: Lawrence Evans, and "Estimation of fatty acids by gas chromatography. Senior Scientific Associate, Expert Committee: (DSN) Dietary Supplements: Non-Botanicals", USP 30 NF 25 Page NO 1203, Pharmacopeial Forum, Vol. 30, No.5, pp. 1668, 2013.

[19] Staff Liaison: Lawrence Evans, "Estimation of Minerals and vitamins. Senior Scientific Associate, Expert Committee: (DSN) Dietary Supplements: Non-Botanicals", USP27-NF22 Page 2063, Pharmacopeial Forum: Vol. 28, No.5, pp.1545, 2013.

[20] Staff Liaison: Lawrence Evans, "Senior Scientific Associate Expert Committee: (DSN) Dietary Supplements: Non-Botanicals" USP27-
NF22 Page 2063 Pharmacopeial Forum: Vol. 28, No. 5, pp. 1545, 2013.

[21] P. Burtin, "Nutritional value of seaweeds", Electronic journal of environmental agricultural and food chemistry, Vol. 2, No. 4, pp. 498-503, 2003.

[22] A. Jensen, "Present and future needs for algae and algal products", Hydrobiology, Vol. 260/261, pp.15-23, 1993.

[23] E. Mendis and S.K. Kim, "Present and Future Prospects of Seaweeds in Developing Functional Foods", Advances in food and nutrition research, Vol. 64, pp.1-15, DOI: 10.1016/B978-0-12-3876690.00001-6, 2011.

[24] S. Polat, and Y. Ozogul, "Fatty acid, mineral and proximate composition of some seaweeds from the northeastern Mediterranean coast", Italian Journal of Food Science, Vol. 21, No.3, pp.317-324, 2009.

[25] C. Dawczynski, R. Schubert, and G. Jahreis, "Amino acids, fatty acids, and dietary fiber in edible seaweed products", Food Chemistry, Vol. 103, No.3, pp. 891-899, 2007.

[26] K. Rohani-Ghadikolalel, E. Abdulalian, and W.K. Ng, "Evaluation of the proximate, fatty acid and mineral composition of representative green, brown and red seaweeds from the Persian Gulf of Iran as potential food and feed resources", Journal of Food Science and Technology, Vol. 49, No.6, pp.774-780, 2012.

[27] X. Li, X. Fan, L. Han, and Q. Lou, "Fatty acids of some algae from the Bohai Sea", Phytochemistry, Vol. 59, pp.157-161, 2002.

[28] S.V. Khotimchenko, V.E. Vaskovsky, and T.V. Titlyanova, "Fatty acids of marine algae from the Pacific coast of North California", Botanica Marina, Vol. 45, pp.17-22, 2002.

[29] V. Gressler, N. Yokoya, M. Fujii, P. Colepicolo, J. Filho, R. Torres, and E. Pinto, "Lipid, fatty acid, protein, amino acid and ash contents in four Brazilian red algae species", Food Chemistry, Vol. 120, pp.585-590, 2010.

[30] V. Venkatesalu, P. Sundaramoorthy, M. Anantharaj, M Gopalakrishnan, and M. Chandrasekaran, "Studies on the fatty acid composition of marine algae of Rameswaram coast", Seaweed Research Utilizatation, Vol. 26, No. 1-2, pp. 83-86, 2004.

[31] D.I, Sanchez-Machado, J. Lopez-Cervantes, J. Lopez-Hernandez, and P. Paseiro-Losada, "Fatty acids, total lipid, protein and ash contents of processed edible seaweeds", Food Chemistry, Vol. 85, pp.439444, 2004

[32] M.M. Nelson, C.F. Phleger, P.D. Nichols, "Seasonal lipid composition in macro algae of the Northeastern Pacific Ocean", Botanica Marina, Vol. 45, 58-65, 2002.

[33] A.E.A. Hamdy, and C.J. Dawes, "Proximate constituents and lipid chemistry in two species of Sargassum from the west coast of Florida", Botanica Marina, Vol. 31, No.1, pp. 79-81, DOI 10.1515/botm.1988.31.1.79, 1998 .

[34] S.V. Khotimchenko, "Fatty acid composition of seven Sargassum species", Phytochemistry, Vol. 30, No. 8, pp. 2639-2641, 1991.

[35] M. Kumar, P. Kumari, N. Trivedi, M.K. Shukla, V. Gupta, C.R.K. Reddy, and B. Jha, "Minerals, PUFAs and antioxidant properties of some tropical seaweeds from Saurashtra coast of India", Journal of Applied Phycology, Vol. 23, No. 5, pp. 797 -810, 2011.

[36] S. Mabeau and J. Fleurence, "Seaweed in food products: biochemical and nutritional aspects", Trends in Food Science and Technology, Vol. 4, pp. 103- 107, 1993.

[37] S. Kaehler and R. Kennish, "Summer and winter comparisons in the nutritional value of marine macro algae from Hong Kong", Botanica Marina, Vol. 39, No. 1-6, pp. 11-17, 1996. 